\title{
Aflatoxincontent of Three Condiments and Their Effects on Some Biochemical and Haematological Parameters in WistarRats
}

\author{
Luka, CarrolDomkat ${ }^{*}$, Tijjani, Habibu ${ }^{2}$ andJoel, Enoch Banbilbwa ${ }^{1}$ \\ ${ }^{1}$ Department of Biochemistry, Faculty of Medical Sciences, University of Jos, Jos, Nigeria \\ ${ }^{2}$ Developmental Biochemistry Research Laboratory, Department of Biochemistry, Bauchi State University, \\ Gadau, Nigeria
}

\begin{abstract}
Condiments as spices are widely used in Nigeria, they provide taste and flavour to meals. In the present study, these condiments; dadawa, ogiri, and okpehewere estimated for aflatoxin contents, their phytochemicals and effects on some biochemical and haematological parameters were also carried out. Twenty four Wistar rats of body weight between $130-180 \mathrm{~g}$ were randomly distributed into four groups of six rats each; Group 1 were control rat which received $0.5 \mathrm{ml}$ of distilled water per day while Groups 2, 3 and 4 received $400 \mathrm{mg} / \mathrm{kg} \mathrm{bw}$. aqueousextracts of dadawa, ogiri and okpehe respectively for 21 days. Phytochemical screening reveals the presence of alkaloids, flavonoid, terpenes and steroids while tannins and balsams were not detected in all condiments. Okpehe has the highestaflatoxin content per $\mathrm{kg}$ followed by dadawa and ogiri respectively. Aqueous extracts significantly $(P<0.05)$ decrease White bloodcells $(W B C)$ in all treated rats while no significant effects $(P>0.05)$ were observed in monocytes of dadawa and ogiritreatedwhen compared to the control. Total protein was significantly decrease $(P<0.05)$ in all treated groups and in albumin content of Ogiri and Okpehe. Also, alanine aminotransferase (ALT) and aspartate aminotransferase (AST) showed significant increase $(P<0.05)$ in all treated groups when compared to the control.Removing aflatoxin from contaminated food and foodstuffs remains a major problem, thereforeaGood Manufacturing Practice (GMP) is highly encouraged in production of these condiments aswellas a close monitoring of their storage and shelf life.
\end{abstract}

Keywords: Aflatoxin, dadawa, haematological parameter, ogiri, okpehe, phytochemicals

\section{Introduction}

Mycotoxins are secondary metabolite produced by organisms of the fungus kingdom commonly known as moulds [1]. The term is usually reserved for the toxic chemicals produced by fungi that readily colonize crops. Aflatoxins are a major type of mycotoxins produced by Aspergillus species of fungi, such as A. flavus and A. parasiticus[2]. There four types of aflatoxins produced by mycotoxins, which are B1, B2, G1 and G2 [3]. AflatoxinB1, the most toxic, is a potent carcinogen and has been directly correlated to adverse health effects, such as liver cancer in the tropics and subtropics[3].

Aflatoxins-producing Aspergilluses are common and widespread in nature. They colonize and contaminate grains before harvest or during storage. Crops which are frequently affected include cereals (maize, sorghum, millet, rice, and wheat), oil seeds (groundnuts, soyabean, sunflower, and cotton), spices (chilli pepper, coconut,Brazil nut), toxins can also be found in milk of animals which arefed with contaminated feed [4]. Favourable conditions for widespread include high moisture content and high temperature [2].

Animal species are not immune to acute toxic effects of aflatoxins including humans; however we, humans have an extraordinary high tolerance for aflatoxin exposure and rarely succumb to acute aflatoxicosis[5]. Acute aflatoxicosis, associated with extremely high doses of aflatoxin, is characterized by hemorrhage, acute liver damage, edema, and death in humans[6]. Some of the other health effects found in animals and humans includeidentifiable diseases or health problems andweakened immune systems [7].

Fermented food condiments have constituted a significant proportion of the diet of many people, Nigerians have exhibited an ambivalent attitude in terms of consumer tastes and preferences for such foods [8], and several of such condiments are available for consumers' choice. Dadawa,OgiriandOkpehe are among the common condiments found in North-central Nigeria. Their production process and storage are source of concern, because of the possibility of microorganism growth which can produce mycotoxins. Parkiabiglobosa, Prosopisafricana and Citrullusvulgarisare plants in which their seeds are commonly used for production of condiments. Dadawa, OgiriandOpkehe are produce from these plantsrespectively. The production process has been described by Achi, [9].The present study was carried out to estimate the aflatoxin content of the three condiments produced by locally fermented-bean and their effects on some Biochemical and Haematological parameters in rats. 


\subsection{Equipment}

\section{Material And Methods}

The following equipmentwere used in the study; Enzyme-linked ImmunoSorbent Assay (ELISA) reader and Kit (Stat Fax® ELISA Reader, Romer Labs Diagnostics GmbH, Technopark 1, Austria), Vortex mixer (VM-1000 Vortex, Digisystem Laboratory, Instruments Inc., Taiwan), Mindray Haematology Analyser (Mindray BC-2300, Guangzhou Shihai Medical Equipment Co., Ltd, China) and other standard laboratory equipment.

\subsection{Collection Of Plant Materials}

The three locally made condiments (Dadawa, Ogiri and Okpehe) were purchased in parts from Terminus market, Jos, Plateau state and Kakuri market, Kaduna south, Kaduna state, Nigeria.

\subsection{Experimental rats}

The experiment animals (Rattus norvegicus) numbering 24 where obtained from the animal house of University of Jos, Nigeria. Rats are of body weight between $130-180 \mathrm{~g}$. The animals were maintained under standard environmental conditions, had free access to food (Grand Cereal Products, Jos, Nigeria) and water $a d$ libitum. Four groups of six rats each were randomly distributed in cages and acclimatized for 7 days.

\subsection{Experimental design}

$\begin{array}{ll}\text { Group 1: } & \text { Control } \\ \text { Group 2: } & \text { Dadawaextract } \\ \text { Group 3: } & \text { Ogiriextract } \\ \text { Group 4: } & \text { Okpehe extract } \\ \text { Each group consist of six animals }(\mathrm{n}=6) & \end{array}$

\subsection{Treatment of experimental animals}

Group 1 received $0.5 \mathrm{ml}$ of distilled water per day, while others (Groups $2-4$ ) received orally 400 $\mathrm{mg} / \mathrm{kg}$ bw.of the condiments as stated for 21 days.

\subsection{Collection of samples}

At $22^{\text {nd }}$ day, the rats were anesthetized at the time of sacrifice by been placed in a seal cotton wool soaked in diethyl ether inhalation jar. Blood samples were collected from the animals in batches. 3 animals' blood samples were separately collected into a clean, dry tube and allowed to cloth for 45 minute and spun at $3000 \mathrm{rpm}$ for 5 minutes before the serum was collected for biochemical assay. Blood sample from the last 3 were separatelycollected into an anti-coagulant and were used for Haematological assay.

\subsection{Phytochemicals}

Phytochemical tests were carried out using standard procedures by Harborne,1973 [10], Trease\& Evans, 1989[11] and Sofowora, 1993 [12].

\subsection{Determination of Aflatoxin}

Ram et al., 1986 [13] method was used in the determination of total aflatoxin by ELISA. Briefly; Aflatoxins were extracted from a grounded sample of each condiment with $70 \%$ methanol. The extracts sample and enzyme-conjugated aflatoxin are then mixed and added to the antibody-coated microwell. Aflatoxins in sample and standard are allowed to compete with enzyme-conjugated aflatoxin for antibody binding site. After a wash step, an enzymesubstrate is added and a blue colour develops. The intensity of the colour is inversely proportional to the concentration of aflatoxin in the sample and standard. The microwells are measured using a microwell reader with an absorbance filter of $450 \mathrm{~nm}$ and a different filter of $630 \mathrm{~nm}$. The optical densities of the samples are compared to the optical density of the standard.

\subsection{Assay of biochemical parameters}

Activities of alanine aminotransferase (ALT) and aspartate aminotransferase(AST) were assayedbythemethodofReitman\&Frankel, 1957 [14]. Total proteins were assayed by Gornellet al., 1949 as modified by Plummer 1978[15] while Albumin was estimated by the methods of Doumaset al., 1971 [16].

\subsection{Haematological parameters}

Haematological parameters were determined using Mindray Haematology Analyser. 


\subsection{Statistical analysis}

Data were presented as Mean \pm SD and wereanalyzed using Duncan multiple range test following oneway analysis of variance (ANOVA) using SPSS 16.0 computer software package (SPSS Inc., Chicago, U.S.A). Differences at $\mathrm{P}<0.05$ were considered significant.

\section{Results}

Total aflatoxin concentration of all condiments as detected by the method of Ram et al., 1989 [13], revel different concentrations with Okpehe having the highest followed by DadawaandOgiri respectively (TABLE I).

Phytochemical screening of the three condiments revel the presence of alkaloids, flavonoids, terpenes and steroids and phenols while tannins and balsams were not detected in all condiments. However, saponnins were not detected in aqueousDadawa and in both aqueous and ethanolicextracts of Ogiri, while resin was absent in aqueous extracts of $O$ giri(TABLE II).

Total protein significantly decrease $(\mathrm{P}<0.05)$ in all treated groups and in Albumin content of Ogiri and Okpehe. Also, ALT and AST showed significant increase $(\mathrm{P}<0.05)$ in all treated groups (TABLE III).

Varying effects of condiments were obtained in the haematological parameters assayed. There was significant decrease $(\mathrm{P}<0.05)$ in WBC of Dadawa, Ogiri and Okpehetreated rats. Significant increases $(\mathrm{P}<0.05)$ were observed in Monocytes and granulocytes of Ogiri treated rats when compared with the control. Significant increases $(\mathrm{P}<0.05)$ were also observed in haemoglobin content of Okpehetreated rats when compared to the control. Significant decrease $(\mathrm{P}<0.05)$ where observed in PCV of Dadawa and Ogiri treated when compared to the control and RBC of Dadawa treated rats. In all assayed parameters, no significant effects $(\mathrm{P}>0.05)$ were observed in monocytes of Dadawa and Okpehe, PCV of Okpehe, \% granulocytes of Dadawa, Ogiri and Okpehe and RBC of Ogiri and Okpehe when compared to the control (TABLE IV).

Table I: Total Aflatoxin Concentration of Condiments

\begin{tabular}{|c|c|c|}
\hline Sample & Amount $(\mathrm{g})$ & Concentration $(\mu \mathrm{g} / \mathrm{kg})$ \\
\hline Dadawa & 5.0 & $3.45 \pm 0.21^{\mathrm{a}}$ \\
\hline Ogiri & 5.0 & $1.95 \pm 0.07^{\mathrm{b}}$ \\
\hline Okpehe & 5.0 & $4.65 \pm 0.21^{\mathrm{c}}$ \\
\hline
\end{tabular}

NOTE: Concentrations are Mean of 2 replicate \pm SD

Values with different superscript are significantly different $(\mathrm{P}<0.05)$ down the column

Table II: Phytochemical Screening of Condiments

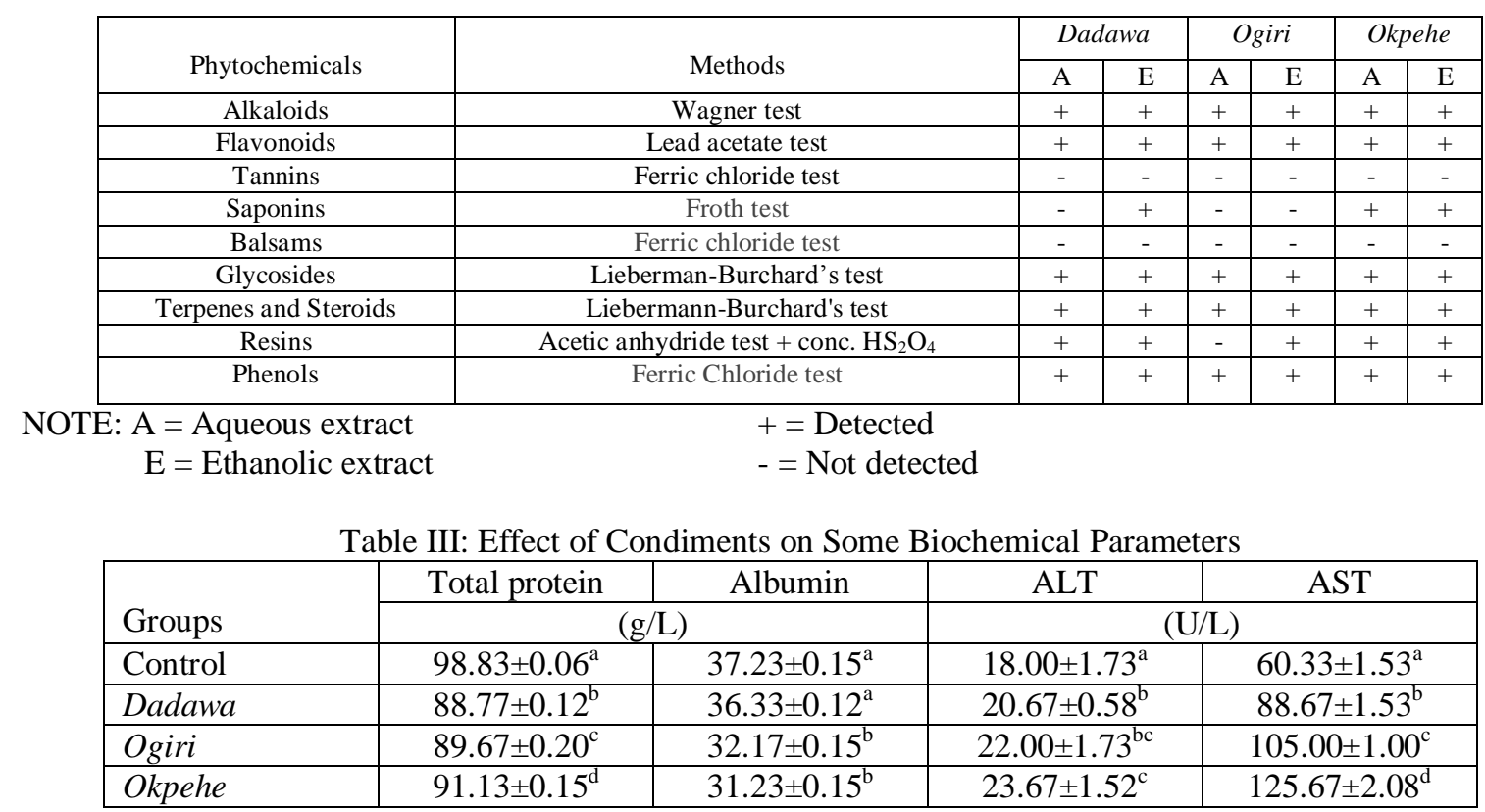

NOTE: Values are Mean of 3 replicates \pm SD

Values with different superscript are significantly different $(\mathrm{P}<0.05)$ down the column 
Table IV: Effects of Condiments on Haematological Parameters

\begin{tabular}{|c|c|c|c|c|}
\hline Parameter & Control & Dadawa & Ogiri & Okpehe \\
\hline $\mathrm{WBC}\left(10^{9}\right) / \mathrm{L}$ & $78.83 \pm 0.58^{\mathrm{a}}$ & $70.77 \pm 0.06^{b}$ & $65.73 \pm 0.06^{\mathrm{c}}$ & $69.43 \pm 0.25^{b}$ \\
\hline Monocytes $\left(\times 10^{9}\right) / \mathrm{L}$ & $1.80 \pm 0.02^{\mathrm{a}}$ & $1.80 \pm 0.01^{\mathrm{a}}$ & $2.10 \pm 0.10^{\mathrm{b}}$ & $1.73 \pm 0.06^{\mathrm{a}}$ \\
\hline Granulocytes $\left(\times 10^{9}\right) / \mathrm{L}$ & $66.67 \pm 0.42^{\mathrm{a}}$ & $63.27 \pm 0.21^{\mathrm{b}}$ & $71.47 \pm 0.40^{\mathrm{c}}$ & $61.90 \pm 0.10^{\mathrm{d}}$ \\
\hline Haemoglobin $(\mathrm{g} / \mathrm{L})$ & $170.33 \pm 1.53^{\mathrm{a}}$ & $156.63 \pm 0.06^{b}$ & $156.30 \pm 0.10^{\mathrm{b}}$ & $175.33 \pm 1.15^{\mathrm{c}}$ \\
\hline $\mathrm{PCV}(\%)$ & $51.13 \pm 1.03^{\mathrm{a}}$ & $47.03 \pm 0.06^{b}$ & $46.93 \pm 0.06^{b}$ & $52.50 \pm 0.36^{\mathrm{a}}$ \\
\hline Platelet /L & $218.00 \pm 2.00^{\mathrm{a}}$ & $218.0 \pm 1.73^{\mathrm{a}}$ & $91.33 \pm 0.58^{b}$ & $137.33 \pm 1.53^{\mathrm{c}}$ \\
\hline Lymphocytes (\%) & $8.51 \pm 0.02^{\mathrm{a}}$ & $8.03 \pm 0.15^{b}$ & $8.78 \pm 0.14^{\mathrm{c}}$ & $8.54 \pm 0.05^{\mathrm{a}}$ \\
\hline Monocytes (\%) & $2.40 \pm 0.01^{\mathrm{a}}$ & $2.63 \pm 0.06^{b}$ & $2.60 \pm 0.01^{\mathrm{b}}$ & $2.50 \pm 0.20^{\mathrm{ab}}$ \\
\hline Granulocytes (\%) & $89.07 \pm 0.40^{\mathrm{ab}}$ & $89.37 \pm 0.15^{\mathrm{a}}$ & $88.57 \pm 0.31^{\mathrm{b}}$ & $89.17 \pm 0.06^{\mathrm{a}}$ \\
\hline Lymphocytes $\left(\times 10^{9}\right) / \mathrm{L}$ & $6.28 \pm 0.15^{\mathrm{a}}$ & $5.70 \pm 0.01^{\mathrm{b}}$ & $7.07 \pm 0.12^{\mathrm{c}}$ & $5.77 \pm 0.15^{b}$ \\
\hline $\operatorname{RBC}\left(\times 10^{12} / \mathrm{L}\right)$ & $8.19 \pm 0.02^{\mathrm{a}}$ & $7.74 \pm 0.02^{b}$ & $8.06 \pm 0.16^{\mathrm{a}}$ & $8.19 \pm 0.02^{\mathrm{a}}$ \\
\hline
\end{tabular}

NOTE: Values are mean of 3 replicates \pm SD

Values with different superscript are significantly different $(\mathrm{P}<0.05)$ across the row

\section{Discussion}

Dangerousmycotoxins are naturally present in food, feeds and our environments [17], making it necessary to evaluate food spices for possible contamination with mycotoxins. Dadawa, Ogiri and Okpehe are condiments marketed by women around the city metropolis and markets. Storage conditions and moisture availability are likely to improve the growth of fungi. Result from this study indicated the presence of aflatoxins in varying concentrations with Okpehe having the highest followed by Dadawa and Ogiri respectively (TABLE I).

Aflatoxins are potent natural carcinogenic substances linked to higher prevalence of hepatocellular cancer in Africa [18], also it has been revealed that high risk occur with hepatitis B and hepatitis C carriers in developing liver cancer when exposed to aflatoxins[5]. Other studies have also linked aflatoxins to immunosuppression and stunted growth in children $[19,20]$. Liver is the principal organ affected by aflatoxins, in the liver, aflatoxin may be transformed by certain $\mathrm{P}_{450}$ enzymes (CYP1A2, 3A4, 3A5, 3A7) to its DNAreactive form aflatoxin-8,9-epoxide. This molecule may bind to liver proteins and lead to their failure, potentially resulting in acute aflatoxicosis[6].

Phytochemical screening revealed the presence of alkaloids, flavonoids, terpenes and steroids, and phenols while tannins and balsams were not detected in all condiments. The toxic effects of tannins have been eliminated in this study due to their absence in the phytochemical screening conducted. Tannins in diets have been reported to have anti-nutritional, antihaemorrhagic and toxic effects including reduced fed intake, growth and net metabolism energy [21, 22]. Saponins were absent in 3 of the 6 extracts, in aqueousDadawa, aqueous and methanolicOgiri. Saponins have also been demonstrated to have antifungal properties [23], their presence would have assisted in preventing the proliferation of fungi.

Biochemical and haematological parameters have been reported to change in toxic effects of aflatoxins, these changes are said to occur before clinical symptoms develop [24, 25]. Several haematological changes where observed in rats treated with the 3 condiments with significant $(\mathrm{P}<0.05)$ changes in all parameters in ogiritreated except for RBC, and monocytes, platelets and \% granulocytes in dadawa treated while okpehe showed no significant effect $(\mathrm{P}>0.05)$ on monocytes, $\mathrm{PCV}$, lymphocytes and RBC.

The changes in haematological parameters maybe due to many factors which have been describe to include inhibition of protein synthesis [26] as seen in low albumin in ogiri and okpehe treated groups, decrease in total iron binding capacity [27] and in haemopoietic cellular defects of aflatoxin contamination [28]. Reductions in PCV and haemoglobin observed in dadawa and ogiri may suggest anaemia which may result from impaired red blood cell production [29, 30]. However, okpehe treated groups express the opposite.

Significant decrease $(\mathrm{P}<0.05)$ in $\mathrm{WBC}$ was observed in all treated groups indicating that the immune system was not activated during the period of treatment, normally a decrease in WBC shows the suppression of leucocytes and their production from bone marrow [31], viscosity of the blood of ogiri treated group maybe adverselyaffected due to increase in monocytes and granulocytes.

Alanine aminotransferase (ALT) and aspartate aminotransferase (AST) in the study were significantly $(\mathrm{P}<0.05)$ increased in all treated groups when compared to the control. These transaminases are two enzymes which are associated with hepatocellular damage and are used as markers for predicting possible toxicity [32]. ALT and AST are elevated in presence of toxic substances [33], these values suggest liver damage by the extracts and resulting increase in ALT and AST in serum of experimental rats.

Condiments when used as spices involve other cooking process after preparation; this can be boiling, steaming or frying. These processes which also include nixtamalization and extrusion cooking can reduce some of the aflatoxin content of the condiments [34], Bankoleet al. [35]however, reported that some aflatoxin still remain at high concentration even after such preparations. 


\section{Conclusion}

The study reveals the presence of aflatoxins in varying concentrations in dadawa, ogiriandokpehe. These condiments when fed to experimental rats increased significantly $(\mathrm{P}<0.05)$ serum ALT and AST indicating their possible toxicity. Even after the different solvents used in extraction, a quit number of phytochemicals were indicated in the extracts. Aflatoxicosis, adverse haemopeotic activities and effects on marker enzymes should encourage a Good Manufacturing Practice to be enforced on the preparation of these condiments and also close monitoring of their storage and shelf life.

\section{References}

[1] NW Turner, S Subrahmanyam, SA Piletsky, "Analytical methods for determination of mycotoxins: a review", Anal. Chim.Acta, 632 (2), 2009, 168-80.

[2] ML Martins,HMMartins, F Bernardo, "Aflatoxinsin spices marketed in Portugal", Food AdditContam, 18 (4), $2001,315-9$.

[3] YN Yin, LY Yan, JH Jiang, ZH Ma, "Biological control of aflatoxin contamination of crops", J Zhejiang UnivSci B, 9(10), 2008, 787-92.

[4] GE Wood, "Mycotoxins in foods and feeds in the United States", J. Anim. Sci., 70 (12), 1992 3941-9.

[5] J Williams, TD Phillips, PE Jolly, JK Stiles, CM Jolly, D Aggarwal, Human aflatoxicosis in developing countries: a review of toxicology, exposure, potential health consequences, and interventions, American Journal of Clinical Nutrition, 80, $2003,1106-1122$.

[6] F Wu, C Narrod, M Tiongco, and Y Liu, The Health Economics of Aflatoxin: Global Burden ofDisease, Aflacontrol, Working Paper 4, P4. http://www.ifpri.org/sites/default/files/publications/aflacontrol_wp04.pdf

[7] K Mahendra. Rai, Shital R. Bonde, Avinash P. Ingle and Aniket K. Gade, Mycotoxin: rapid detection, differentiation and safety, J Pharm Educ Res, 3 (1), 2012.

[8] OK Achi, Microorganisms associated with natural fermentation of prosopisAfricana seeds for the production of Okpiye plant Foods, Hum. Nutr., 42, 1992, 297-304.

[9] O. K. Achi, Traditional fermented protein condiments in Nigeria, African Journal of Biotechnology, 4 (13), $2005,1612-1621$.

[10] J. B. Harborne, Phytochemical Methods. Chapman and Hall Ltd., London 1973, 49-188.

[11] G. E. Trease, and W.C. Evans, Pharmacognosy, 11thedn., BailliereTindall, London, 1989, 45-50.

[12] A. Sofowora, Medicinal plants and traditional medicine in Africa, Spectrum Books Ltd., Ibadan, Nigeria, $1993,289$.

[13] BP Ram, LP Hart,OLShotwell, and JJ Pestka,Enzyme-linked immunosorbent assay of aflatoxin B1 in naturally contaminated corn and cottonseed 1, Assoc. Off. Anal.Chern., 69,1986, $904-907$.

[14] S. Reitman, and S. Frankel, A colorimetric method for the determination of serum glutamic oxaloacetic and glutamic pyruvic transaminase, American Journal of Clinical Pathology,28, 1957,56-63.

[15] DT Plummer, An introduction to practical Biochemistry, 2nd Edition. McGraw-Hill, London, 1978, $144-145$.

[16] BT Doumas, WA WatsonandHC Biggs, Albumin standards and Management of serum albumin with bromocresol green, Chin. Chim.Acta, 31, 1971, 87-96.

[17] R Dragan, Milicevic, M Skrinjar, and T Baltic, Real and Perceived Risks for Mycotoxin Contamination in Foods and Feeds: Challenges for Food Safety Control, Toxins, 2, 2010, 572-592.

[18] H Strosnider, E Azziz-Baumgartner,MBanziger, RV Bhat, R Breiman, MN Brune, et al., Workgroup report: public health strategies for reducing aflatoxin exposure in developing countries, Environmental Health Perspectives, 114, 2006, $1898-1903$.

[19] PC Turner, SE Moore, AJ Hall, AM Prentice, CP Wild, Modification of immune function through exposure to dietary aflatoxin in Gambian children, Environ Health Perspect, 111(2), 2003, 217-220.

[20] F Wu, P Khlangwiset, Health economic impacts and cost-effectiveness of aflatoxin reduction strategies in Africa: Case studies in biocontrol and postharvest interventions, Food Additives \& Contaminants, 27, 2010, 496-509.

[21] T Acamovic, and J.D. Brooker, Biochemistry of plant secondary metabolites and their effects in animals, Proc. Nut. Soc., 4, 2005, 403-412.

[22] TN Asquith, and L.G. Butler,Interaction of condensed Tannins with selected proteins, Photochemistry, 25(7), 1986, 1591-1593.

[23] GGE Osuagwu, I.C. Okwulehie and J.O. Emenike, Photochemical and Mineral content of the leaves of four Nigerian Pterocarpusspecies, Int. J. Mol. Med. Adv. Sci., 3(1), 2007, 6-11.

[24] M. V. L. N. Raju and G. Devegowda, "Influence of esterified glucomannan on performance and organ morphology, serumbiochemistry and haematology in broilers exposed to individual and combined mycotoxicosis (aflatoxin, ochratoxin and T-2 toxin)," British Poultry Science, 41(5), 2000, 640-650.

[25] K. L. Arawind, V. S. Patil, G. Devegowda, B.Umakantha, and S.P. Ganpule, "Efficiacy of esterified glucomannan to counteract mycotoxicosis in naturally contaminated feed on performance and serum biochemical, haematological parameters in broilers," Poultry Science, (82), 2003, 571-576.

[26] J. J. Kaneko,Clinical, Chemistry of Domestic Animals, Academic Press, San Diego, Calif, USA, 4th edition, 1989.

[27] R. B. Harvey, L. F. Kubera, T. D. Phillips, D. E. Cornier, M. H. Ellisade, and W. E. Huff, "Dimunition of aflatoxin toxicity to growing lambs by dietary supplementation with HSCAS," American Journal of Veterinary Research, 52, 1991,152-156.

[28] M. A. Abdel-Wahhab, S. A. Nada, and F. A. Khalil, "Physiological and toxicological responses in rats fed aflatoxincontaminated diet with or without sorbent materials," AnimalFeed Science and Technology, 97(3-4), 2002,209-219.

[29] PR Cheeke, Natural toxicants in feeds, forages and poisonous plants. $2^{\text {nd }}$ Edition. IL: Interstate Publishers, Danville, 1998.

[30] RR Seeley, TD Stephens, and P Tate, Essentials of anatomy and physiology. $4^{\text {th }}$ Edition.WCB/ McGraw Hill Companies, New York, $1998,465$.

[31] SO Odesanmi, RA Lawal, and SA Ojokuku, Haematological effects of ethanolic fruit extract of Tetrapleuratetraptera in male Dutch white rabbits, Res J. Med. Plant, 4, 2010, 213-217.

[32] OA Ojiako, and HU Nwanyo, Is Vernoniaamygdalinahepatotoxic or hepatoprotective?. Response frombiochemical and toxicity studies in rats, $A$. J. Biotech,5(10), 2006, 745-750.

[33] H Varley, AHGowenlock, JR McMurray, DM Mc.Lauchlan, Varley’s Practical Clinical Biochemistry, Eds. 6th ed. London: Heinemann Medical Books 1988, 503, 535-2.

[34] BM Ogunsanwo, OO Faboya, OR Idowu, OS Lawal, and SA Bankole, Effect of roasting on the aflatoxin contents of Nigerian peanut seeds, African Journal ofBiotechnology,3(9), 2004, 451-455.

[35] SA Bankole, BM Ogunsanwo, and DA Eseigbe,Aflatoxins in Nigerian dry roasted groundnuts, Food Chemistry, 89, 2005, 503-506. 